\title{
Thalamic infarction in pituitary apolplexy syndrome
}

\author{
Rajesh Verma, ${ }^{1}$ Sunil Singh, ${ }^{1}$ Tushar B Patil ${ }^{2}$ \\ ${ }^{1}$ Department of Neurology, Chhatrapati Shahuji Maharaj Medical University, Lucknow, Uttar Pradesh, India \\ ${ }^{2}$ Department of Neurosurgery, Chhatrapati Shahuji Maharaj Medical University, Lucknow, Uttar Pradesh, India
}

Correspondence to Professor Rajesh Verma, drrajeshverma32@yahoo.com

\section{DESCRIPTION}

A 36-year-old man presented with drooping of both eyelids and diminution of vision in both eyes for 7 days, preceded by fever and headache for 15 days. He had diplopia, accentuated in looking forward. He did not complain of difficulty in mastication, impaired swallowing, weakness in any limb or fluctuations in symptoms. The patient's history was negative for head trauma, anticoagulants and other drugs or endocrinopathy. A general physical survey revealed bilateral gynaecomastia. He had bilateral vision loss, visual acuity being $6 / 24$ in right eye and $6 / 36$ in left eye. Right pupil was dilated with sluggish reaction and left pupil was mildly dialated with impaired reaction. The patient had bilateral ptosis which was more marked in left eye. On primary gaze, left eye was abducted and externally rotated (figure 1). Adduction and upward movements of both eyeballs were restricted (figure 2). Thus, he had a partial right oculomotor (third

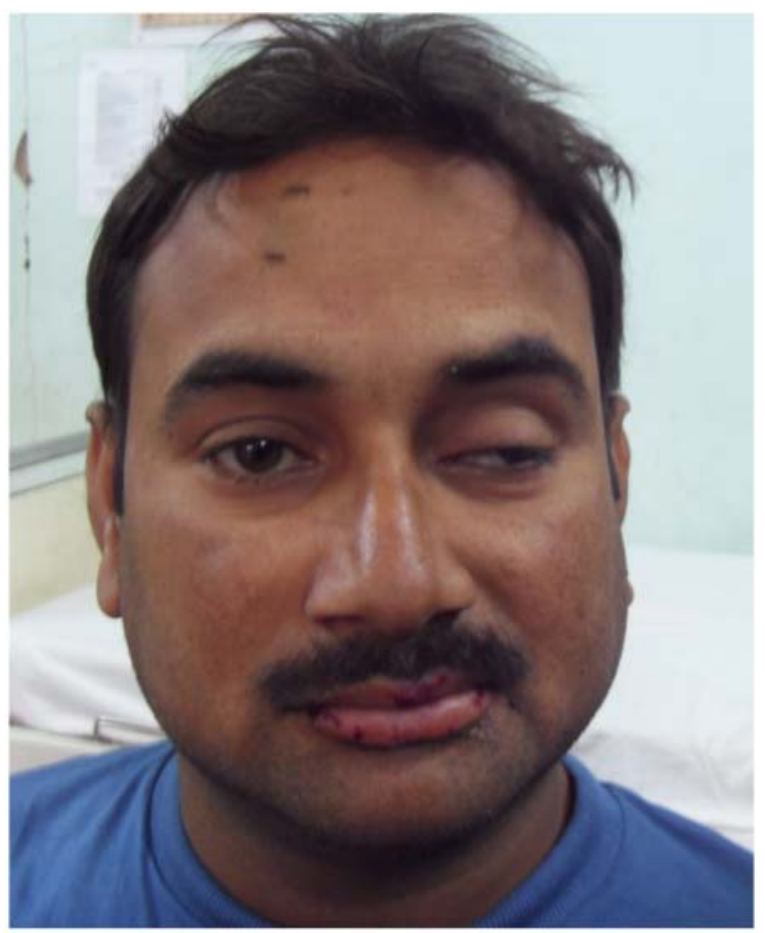

Figure 1. Patient photograph revealing ptosis, more marked in left eye. On primary gaze, left eye is abducted and externally rotated. cranial nerve) palsy and a complete left oculomotor palsy. Rest of the neurological examination was unremarkable. Routine hematological and biochemical parameters were normal. Hormonal assay revealed growth hormone, $0.06 \mathrm{ng} / \mathrm{ml}$ (normal range 2.1-17.7); thyroid stimulating hormone, $21.83 \mu \mathrm{IU} / \mathrm{ml}(0.35-5.5)$; T3, $31 \mathrm{ng} / \mathrm{dl}$ (60-200); $\mathrm{T} 4,1.5 \mu \mathrm{g} / \mathrm{dl}(4.5-12)$ and serum prolactin, $3.71 \mathrm{ng} / \mathrm{ml}$ (normal 2.1-17.7). MRI cranium revealed heterogeneousenhancing extraxial space occupying lesion in sellar region with suprasellar extension diagnostic of pituitary macroadenoma (figure 3). Other findings were acute infarct in left thalamus and adjoining midbrain (figure 4). Thus, a diagnosis of pituitary apoplexy with thalamic and midbrain infarction was made. He was treated with steroids and an emergent transphenoidal decompression surgery for pituitary macroedema. Histopathology of the resected tumour showed large areas of ischaemic necrosis with round to polygonal tumour cells and dispersed chromatin

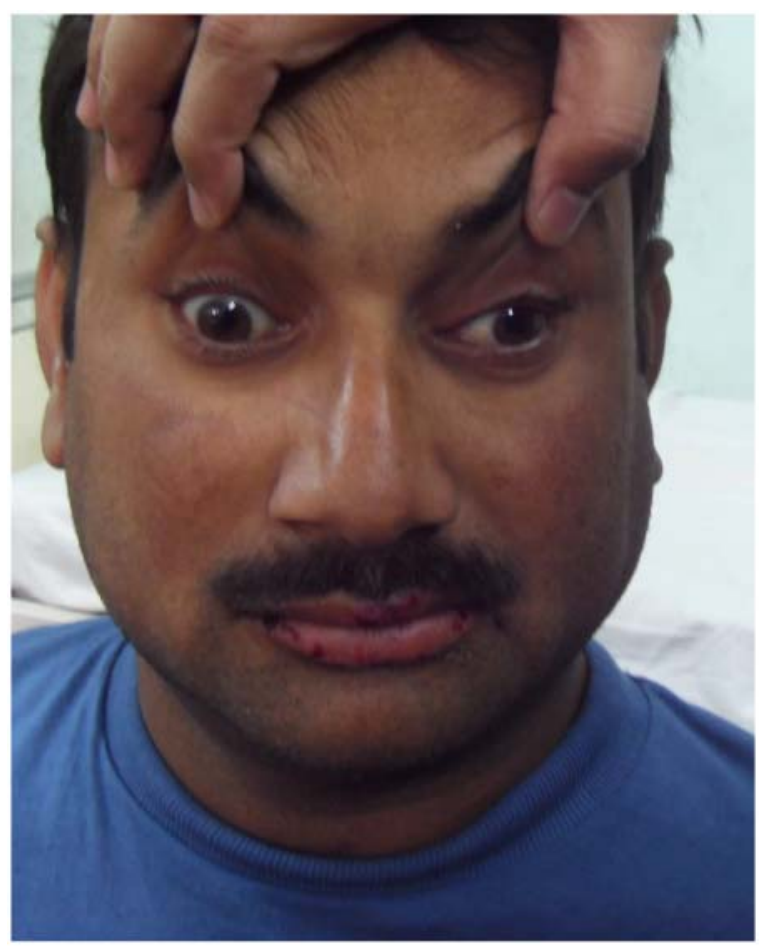

Figure 2. Patient image showing restriction in adduction and supraduction. 


\section{BMJ Case Reports}

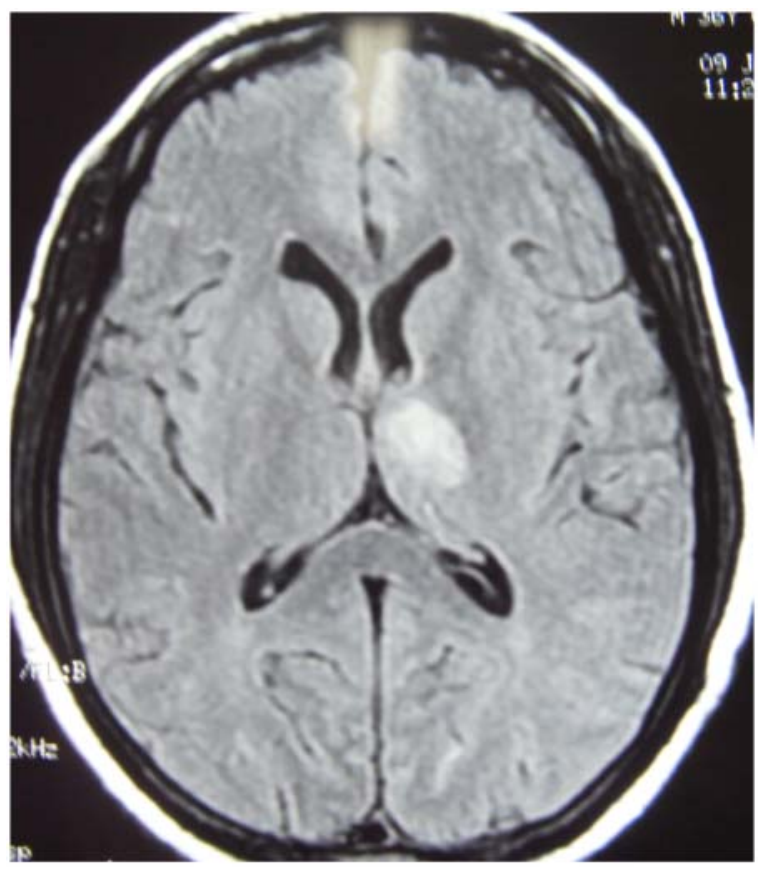

Figure 3. T1 MRI contrast image revealing mass in sellar and suprasellar region with mixed hypointense and hyperintense signals and rim enhancement.

consistent with diagnosis of pituitary adenoma (figure 5). In follow-up patient showed remarkable clinical improvement.

Pituitary apoplexy syndrome occurs due to infarction or haemorrhage in pituitary gland or a pre-existing adenoma and presents with vision loss, ophthalmoplegia, impaired mentation, meningismus and endocrinal abnormalities. ${ }^{1}$

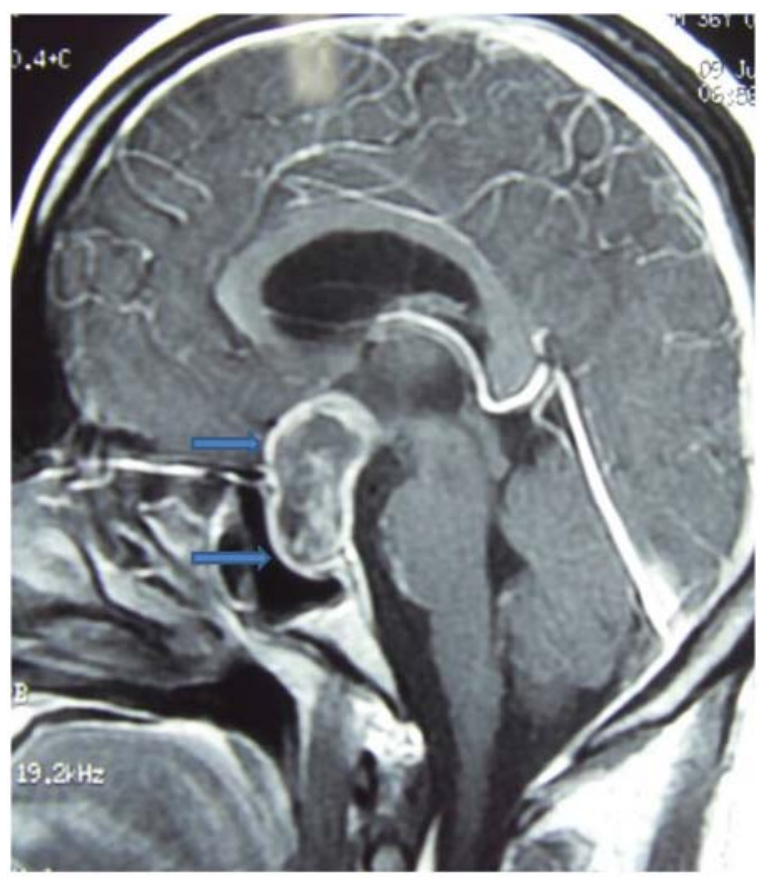

Figure 4. T2 fluid attenuated inversion recovery showing infarct in left thalamic region.

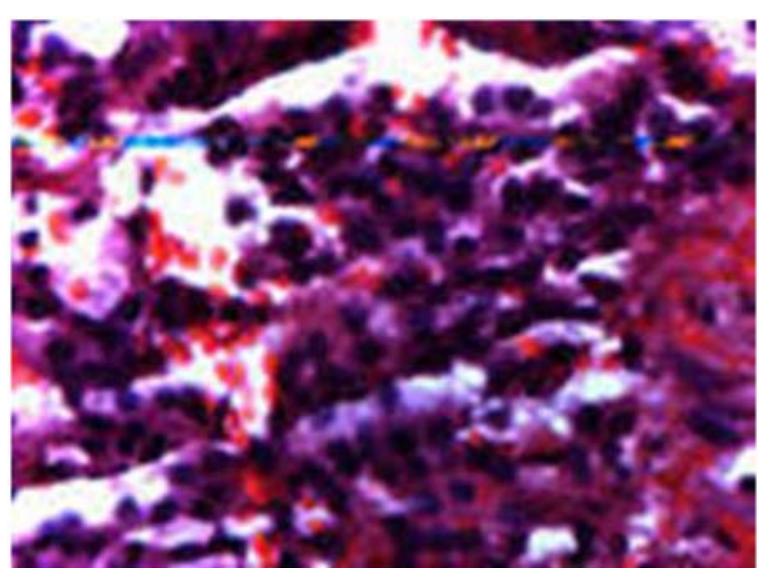

Figure 5. Histopathology showed large areas of ischaemic necrosis with round to polygonal tumour cells and dispersed chromatin consistent with diagnosis of pituitary adenoma.

A concurrent cerebrovascular episode with a stroke is a rare occurrence. Previously described case reports have mentioned pituitary apoplexy-associated strokes in internal or middle cerebral artery territory presenting with hemiparesis. However, isolated thalamic stroke has not been yet described. According to existing literature, stroke in such cases has been described to occur due to one of the following mechanisms ${ }^{2}{ }^{3}$ : (1) compression of intracavernous portion of internal carotid artery due to expanding pituitary adenoma or a haemorrhage within it; (2) vasospasm caused by factors released from haemorrhagic or necrotic material. Thalamic infarction in our patient was probably due to vasospasm secondary to factors released from haemorrhagic or necrotic material from pituitary. However, exact explanation usually remains elusive in such cases.

Learning points

- Pituitary apoplexy syndrome although rare is a life-threatening neurological disorder of emergent nature.

- Thalamic infarction has not been reported previously in the literature.

- So any patient presenting with bilateral ptosis, vision loss and impaired mentation which can occur in posterior territory stroke should also be examined for pituitary apoplexy syndrome.

\section{Competing interests None.}

Patient consent Obtained.

\section{REFERENCES}

1. Bills DC, Meyer FB, Laws ER, et al. A retrospective analysis of pituitary apoplexy. Neurosurgery 1993;33:602-9.

2. López Hernández N, García Escrivá A, Moltó Jordá JM, et al. Massive cerebral infarction secondary to apoplexy due to pituitary adenoma. Neurologia 2008:23:248-55.

3. Ahmed SK, Semple PL. Cerebral ischaemia in pituitary apoplexy. Acta Neurochir (Wien) 2008;150:1193-6. 
This pdf has been created automatically from the final edited text and images.

Copyright 2012 BMJ Publishing Group. All rights reserved. For permission to reuse any of this content visit http://group.bmj.com/group/rights-licensing/permissions.

BMJ Case Report Fellows may re-use this article for personal use and teaching without any further permission.

Please cite this article as follows (you will need to access the article online to obtain the date of publication).

Verma R, Singh S, Patil TB. Thalamic infarction in pituitary apolplexy syndrome. BMJ Case Reports 2012;10.1136/bcr-2012-006993, Published XXX

Become a Fellow of BMJ Case Reports today and you can:

- Submit as many cases as you like

- Enjoy fast sympathetic peer review and rapid publication of accepted articles

- Access all the published articles

- Re-use any of the published material for personal use and teaching without further permission

For information on Institutional Fellowships contact consortiasales@bmjgroup.com

Visit casereports.bmj.com for more articles like this and to become a Fellow 